\title{
EVALUATION OF IN VITRO PROTEIN DIGESTIBILITY OF Moringa oleifera LEAVES WITH VARIOUS DOMESTIC COOKING
}

\author{
Harum Fadhilatunnur ${ }^{1 *}$, Fransisca $^{2}$ and Rike Tri Kumala Dewi ${ }^{2}$ \\ ${ }^{1}$ Department of Food Science and Technology, Faculty of Agricultural Technology, IPB University, Bogor, \\ Indonesia \\ ${ }^{2}$ Department of Food Business Technology, School of Applied Science, Technology, Engineering, and \\ Mathematics, Universitas Prasetiya Mulya, BSD City, Indonesia \\ *harum@apps.ipb.ac.id \\ https://doi.org/10.34302/crpjfst/2021.13.1.18 \\ Article history: \\ Received: \\ Accepted: \\ 23 April 2020 \\ 25 February 2021 \\ Keywords: \\ Antinutritional coumpound; \\ Domestic cooking; \\ Moringa oleifera; \\ Protein content; \\ Pepsin digestibility.

\section{ABSTRACT} \\ Moringa oleifera is gaining attention for having high protein content with \\ balanced amino acid composition. However, as in other plant-based protein, \\ its protein digestibility becomes of concern presumably due to the presence \\ of antinutritional compounds such as tannins, phytic acid, and saponins. In \\ this study, the effect of domestic cooking (blanching, steaming, boiling, and \\ sautéing) to protein content, protein digestibility, and antinutritional \\ compounds of Moringa leaf powder was investigated. Analysis revealed that \\ the Moringa leaf powder contained $33.12 \%$ protein (with $90.52 \%$ pepsin \\ digestibility), $41.97 \%$ carbohydrates, $7.56 \%$ fat, $9.77 \%$ ash, and $33.88 \%$ \\ dietary fiber. The protein content and pepsin digestibility $(>84 \%)$ were \\ notably high and were comparable to those of other plant-based protein \\ sources, such as soybean and peas. Protein content tend to increase with \\ domestic cooking. The treatments applied did not manage to reduce phytic \\ acid and saponins. Blanching and boiling significantly reduced the tannin \\ content while, blanching and sautéing increased the saponin content. The \\ pepsin digestibility remained the same despite of reduction in tannins. \\ Correlation study showed that among the three antinutritional compounds, \\ it was saponin which adversely affect the pepsin digestibility of Moringa \\ leaf powder $(\mathrm{r}=-0.463)$. Overall, boiling seemed to be the best method of \\ cooking for Moringa leaves in term of protein content and pepsin \\ digestibility.
}

\section{Introduction}

Moringa oleifera, best known as "kelor" in Indonesia, is often referred as one of the most potential commodities to combat malnutrition due to its rich and balance nutrient composition (Moyo \& Masika, 2011; Mune Mune, Nyobe, Bassogog, \& Minka, 2016; Teixeira, Carvalho, Neves, Silva, \& Arantres-Pereira, 2014; Titi, Harijono, Estiasih, \& Endang, 2013). The plant is indigenous in South Asia, but has been widely distributed in many tropical and subtropical countries, including Indonesia (Moyo \& Masika, 2011). Moringa oleifera is a perennial foliaged tree that can grow around 7-11 meters tall. The tree is widely cultivated for its functionality and high adaptability to dry condition.

Almost all parts of the tree can be used for food, traditional medicines, and for industrial purposes. As food, the leaves are probably the most utilized part among others. The protein content in Moringa leaves is found to be comparable to that of legumes, such as soy beans and black beans (Mune Mune et al., 2016). Additionally, it is reported that 19 out of 20 essential amino acids are present in Moringa 
leaves and are in balanced proportion (Anwar, Latif, Ashraf, \& Gilani, 2007; Johnson, 2005). In Africa region, Moringa leaves are recommended for breast-feeding mothers and children to help meeting their iron and protein needs. In Indonesia, Moringa leaves are consumed as nutritive vegetables, to boost breast milk production and to cure anemia (Sallau, Mada, Ibrahim, \& Ibrahim, 2012; Titi, Harijono, Estiasih, \& Endang, 2013).

It is known that protein quality depends on both amino acid composition and protein digestibility. Many studies reported that plant protein tend to have lower digestibility compared to animal protein, presumably due to the presence of antinutritional compounds. Moringa and other plants alike contain several antinutritional compounds such as tannins, phytic acid, and saponins (Sallau et al., 2012). These components may form complex with proteins, enzymes, or minerals and hamper their digestion (Liener, 2003). In the case of malnourished patients or when this type of foodstuffs become the main source of protein, this condition may greatly affect the health of its consumers.

Processing methods such as boiling, soaking, heating, steaming, and fermentation have been reportedly reduce the antinutritional compunds in food stuff (Fabbri \& Crosby, 2016; Hefnawy, 2011; Titi, et al., 2013; Yang, Tsou, \& Lee, 2002). However, report on the effect of such processes on the antinutritional compunds of Moringa as well as the correlation on its digestibility is still limited. Hence, this study aimed to evaluate the effect of domestic processing on protein content, antinutritional compounds, and the in vitro protein digestibility of Moringa leaves.

\section{Materials and methods}

\subsection{Sample collection and preparation}

Moringa leaves were purchased from local farmer in Tangerang Selatan, Banten, Indonesia. Fresh leaves were packed in plastic container to the laboratory.

Fresh Moringa leaves were washed and subjected to 4 (four) treatments; blanching, steaming, boiling, and sautéing, with raw/ untreated leaves as control. For blanching, Moringa leaves were blanched in boiling water for 5 minutes followed by immediate cooling in cold water. For steaming, Moringa leaves were steamed for 5 minutes. For boiling, Moringa leaves were immersed in boiling water for 15 minutes. For sautéing, Moringa leaves were sautéed in preheated cooking oil (temperature of $180^{\circ} \mathrm{C}$ ) for 5 minutes. The excess oil was then removed with hexane. The treated and raw (control) Moringa leaves were drained and dried in oven at temperature of $45^{\circ} \mathrm{C}$. Dried leaves were then milled into powder and were subjected to analyses.

\subsection{Analysis of Chemical Composition}

The percentages of protein, lipids, ash, moisture, and dietary fiber were determined by standard methods of the AOAC International (2012). Carbohydrates were calculated by difference. Iron content was determined by Atomic Absorption Spectrometry (AAS).

\subsection{Analysis of Antinutritional Compounds}

Tannins were determined by spectrophotometry at $725 \mathrm{~nm}$ as described in Makkar, Blummel, Borowy, and Bekker (1993). Total tannins were calculated as the difference of total phenols prior to and after tannin removal from the sample extract using polyvinylpyrrolidone. Phytic acid content was determined by spectrophotometry as described in Haug and Lantzsch (1983). Samples were extracted with $\mathrm{HNO}_{3}$ and reacted with $\mathrm{FeNH}_{4}\left(\mathrm{SO}_{4}\right)_{2}$. Following centrifugation, the filtrate was then reacted with $\mathrm{NH}_{4} \mathrm{CNS}$ and its absorbance was measured at $465 \mathrm{~nm}$. Saponin was determined by spectrophotometry at $544 \mathrm{~nm}$ as described in Hiai, Oura, and Nakajima (1976). Methanol-extract of the sample was reacted with vanillin solution and $72 \% \mathrm{H}_{2} \mathrm{SO}_{4}$ followed by measurement of absorbance at 465 nm.

\subsection{Analysis of Pepsin Digestibility}

Protein digestibility was analysed based on their susceptibility to pepsin (Association of 
Official Analytical Chemists [AOAC], 2012). Defatted samples were digested with warm solution of pepsin for 16 hours under constant agitation. The insoluble residues obtained were then washed, dried, and analysed for its remaining protein content.

\subsection{Statistical analysis}

All analyses were performed at least in duplicate and results were subjected to analysis of variance (ANOVA). Significant difference between means were determined by Duncan test at 5\% significance level. Data were expressed as mean $\pm \mathrm{SD}$.

\section{Results and discussions}

\subsection{Chemical composition}

Chemical composition of Moringa leaf powder (control) is presented in Table 1. Moringa leaf powder was found to contain $41.97 \%$ carbohydrates, $33.12 \%$ protein, $7.56 \%$ lipid, $7.02 \%$ moisture, $9.77 \%$ ash, $33.88 \%$ dietary fiber, and $7.8 \mathrm{ppm}$ iron. Protein was the second major macronutrient in Moringa leaf powder after carbohydrates.

Table 1. Macronutrients, fiber, and iron of Moringa leaf powder and common legumes

\begin{tabular}{|l|c|c|c|c|c|c|}
\hline Commodity & $\begin{array}{c}\text { Protein } \\
(\mathbf{\%})\end{array}$ & $\begin{array}{c}\text { Carbohydr } \\
\text { ate (\%) }\end{array}$ & $\begin{array}{c}\text { Lipid } \\
\mathbf{( \% )}\end{array}$ & Ash (\%) & $\begin{array}{c}\text { Dietary } \\
\text { fiber } \\
(\%)\end{array}$ & References \\
\hline $\begin{array}{l}\text { Moringa leaf } \\
\text { powder }\end{array}$ & $33.12 \pm 0.66$ & $41.97 \pm 0.32$ & $7.56 \pm 0.17$ & $9.77 \pm 0.00$ & $33.88 \pm 0.29$ & \\
\hline Soybean & 37.81 & 31.92 & 20.65 & 4.46 & 9.6 & USDA (2019) \\
\hline Chickpea & $23.7 \pm 1.1$ & $61.1 \pm 1.8$ & $4.8 \pm 0.1$ & $2.2 \pm 0.0$ & $14.8 \pm 0.4$ & $\begin{array}{c}\text { Sreerama } \\
(2012)\end{array}$ \\
\hline Cowpea & $24.1 \pm 0.9$ & $63.3 \pm 1.2$ & $2.3 \pm 0.0$ & $2.9 \pm 0.0$ & $14.1 \pm 0.3$ & $\begin{array}{c}\text { Sreerama } \\
(2012)\end{array}$ \\
\hline Horse gram & $22.5 \pm 1.0$ & $66.6 \pm 2.1$ & $1.4 \pm 0.0$ & $2.7 \pm 0.0$ & $16.3 \pm 0.5$ & $\begin{array}{c}\text { Sreerama } \\
(2012)\end{array}$ \\
\hline
\end{tabular}

Out of all its nutritional components, it is mainly the protein content that becomes of attention. Lower protein values of Moringa leaves were reported by Mune Mune et al. (2016), Teixeira et al. (2014), Moyo and Masika (2011), and Olabode, Akanbe, Olunlade, and Adeola. (2015), which were $18.63 \%, 28.65 \%$, $30.29 \%$, and $31.33 \%$ respectively. This difference could be attributed to difference of cultivar and/or environmental condition.

Compared to that of soybean, the protein content of Moringa leaf powder was still lower (Table 1). Soybean, which currently is the main plant-based protein source in Indonesia, contain considerably high protein content at $37.81 \%$ (United States Department of Agriculture (USDA), 2019). However, protein content of Moringa leaf powder was still higher than that of the alternative commodities such as chickpeas $(23.7 \%)$, cowpeas $(24.1 \%)$, and horse gram
(22.5\%) (Sreerama, Sashikala, Pratape, \& Singh, 2012). This level of protein suggests the potential of Moringa as alternative protein source to animal protein, together with soybean and other common legumes.

\subsection{Effect of cooking on antinutritional compounds}

Table 2 displayed the tannin, phytic acid, and saponin content of Moringa leaf powder. Untreated Moringa leaf powder (control) recorded $0.60 \%$ tannins, $2.23 \%$ phytic acid, and $8.72 \%$ saponins. The level of tannins was slightly higher than the $0.31 \%$ of condensed tannins by Moyo and masika (2011) but lower than the $2.06 \%$ of total tannins reported by Teixeira et al. (2014). The level of phytic acid and saponins in this study were significantly higher than those found by Devisetti et al. (Devisetti, Sreerama, \& Bhattacharya, 2016) at 
$0.35 \%$ and $1.6 \%$ respectively, but more similar to the finding by Makkar and Bekker (1996), which were $3.1 \%$ and $5 \%$ for phytic acid and saponins.

Table 2. Protein, tannin, phytic acid, saponin content, and pepsin digestibility of Moringa leaf powder with different domestic cooking

\begin{tabular}{|l|c|c|c|c|c|}
\hline Treatment & $\begin{array}{c}\text { Protein } \\
(\mathbf{g} / \mathbf{1 0 0} \mathbf{g})\end{array}$ & $\begin{array}{c}\text { Tannin } \\
(\mathbf{g} / \mathbf{1 0 0} \mathbf{g})\end{array}$ & $\begin{array}{c}\text { Phytic acid } \\
(\mathbf{g} / \mathbf{1 0 0} \mathbf{g})\end{array}$ & $\begin{array}{c}\text { Saponin } \\
(\mathbf{g} / \mathbf{1 0 0} \mathbf{g})\end{array}$ & $\begin{array}{c}\text { Pepsin } \\
\text { digestibility (\%) }\end{array}$ \\
\hline Control & $33.12 \pm 0.66^{\mathrm{a}}$ & $0.60 \pm 0.27^{\mathrm{a}}$ & $2.23 \pm 0.12^{\mathrm{a}}$ & $8.72 \pm 0.29^{\mathrm{a}}$ & $90.52 \pm 1.58$ \\
\hline Blanching & $35.10 \pm 0.75^{\mathrm{b}}$ & $0.12 \pm 0.06^{\mathrm{b}}$ & $2.35 \pm 0.55^{\mathrm{ab}}$ & $11.96 \pm 0.30^{\mathrm{b}}$ & $84.48 \pm 4.98$ \\
\hline Steaming & $31.48 \pm 0.52^{\mathrm{c}}$ & $0.56 \pm 0.34^{\mathrm{a}}$ & $2.33 \pm 0.95^{\mathrm{ab}}$ & $8.36 \pm 0.16^{\mathrm{a}}$ & $89.04 \pm 6.13$ \\
\hline Boiling & $34.83 \pm 0.69^{\mathrm{b}}$ & $0.22 \pm 0.07^{\mathrm{b}}$ & $2.42 \pm 0.14^{\mathrm{b}}$ & $8.45 \pm 0.56^{\mathrm{a}}$ & $91.02 \pm 10.62$ \\
\hline Sautéing & $33.37 \pm 0.27^{\mathrm{a}}$ & $0.41 \pm 0.06^{\mathrm{ab}}$ & $2.19 \pm 0.13^{\mathrm{a}}$ & $12.46 \pm 1.05^{\mathrm{b}}$ & $88.14 \pm 5.57$ \\
\hline
\end{tabular}

Note: Means in the same column with different letters $(\mathrm{a}-\mathrm{c})$ are significantly $(\mathrm{p}<0.05)$ different

A general reduction in tannin content was observed upon cooking, with blanched and boiled leaves showed significantly the greatest reduction (Table 2). Tannins were recorded at $0.56 \%$ and $0.41 \%$ in steamed and sautéed samples, which were not significantly different ( $p>0.05$ ) from that the $0.60 \%$ in control. In blanched and boiled samples, tannins were found at $0.12 \%$ and $0.22 \%$, which were significantly lower $(p<0.05)$ than that of the control. This could be attributed to tannin's properties being heat sensitive and water soluble (Liener, 2003). During blanching and boiling, Moringa leaves were immersed in boiling water. Part of tannins would likely be degraded and leach into the water, causing significant reduction in tannins. This finding was in agreement with previous studies which also demonstrated the decreased in tannins with boiling treatment in yellow field peas (Ma, Boye, \& Hu, 2017), lentils (Hefnawy, 2011), and various types of beans and peas (Habiba, 2002; Wang, Hatcher, Tyler, Toews, \& Gawalko, 2010). During sautéing and steaming, there was no direct contact of Moringa leaves with liquid water. It suggested that the degradation of tannins in these two treatments was solely due to the heat but was simply not able to cause a significant reduction compared to control.

There was no reduction in phytic acid observed with given treatments in this study. This result was in agreement with Wang, et al. (2010) who also reported no significant changes in phytic acid content of beans and chickpeas upon cooking (combination of soaking and boiling). Phytic acid is relatively heat stable but can be broken down hydrolytically by enzymes or by heat in combination with acid (Konietzny \& Greiner, 2003; Liener, 2003). Prolonged soaking, germination, as well as fermentation may increase the exposure of phytic acid to endogenous or microbial phytase, which in turn reduce the phytic acid or phytate content (Gilani, Cockell, \& Sepher, 2005). Soaking may activate endogenous phytase (Margier et al., 2018). Germination significantly increased phytase activity presumably via de novo synthesis in cereal grains (Azeke, Egielewa, Eigbogbo, \& Ihimire, 2011). But, none of the three treatments were performed in this study. Meanwhile, heat treatment alone was reported to be ineffective to reduce phytate content (Liener, 2003). This explains why the phytic acid contents of the samples remained similar in this study. However, different results were reported by Sallau et al. (2012) who observed significant phytic acid reduction in Moringa leaves with boiling, simmering, and blanching treatment.

There was also no reduction in saponins observed with given treatments in this study. The blanched and sautéed samples showed significantly higher level of saponins $(11.96 \%$ and $12.46 \%$ ) compared to that of control, steamed, and boiled samples $(8.72 \%, 8.36 \%$, and $8.45 \%$ respectively). Study by Duhan et al. (2001) demonstrated that the level of saponins in pigeon pea cultivars decreased with cooking. 
However, saponins are reported to be stable to heating and that their biological activity does not decrease with normal cooking (Savage, 2003). This is the reason why there is no reduction in saponin level observed with various heat treatments applied. It is not clear why the level of saponins was significantly higher in the blanched and sautéed samples.

The effect of domestic cooking on dietary fiber was not analyzed in this study. However, it is expected that the level would not greatly change as previous studies have demonstrated that total dietary fiber was not affected by heating and drying in Moringa leaves (Devisetti et al., 2016) and by boiling, roasting, and pressure cooking in pearl millet (Pushparaj \& Urooj, 2011).

\subsection{Effect of cooking on protein content and pepsin digestibility}

The protein content and pepsin digestibility of Moringa leaf powder with different domestic cooking are presented in Table 2 . In addition to high protein content, Moringa leaf powder showed high pepsin digestibility ( $>84 \%)$. Becker (as cited in Teixeira et al., 2014) assessed fodder of fresh Moringa leaves and observed more similar value of in vitro protein digestibility $(79 \%)$.

The protein content of Moringa leaf powder were $33.12 \%, 35.10 \%, 31.48 \%, 34.83 \%$, and $33.37 \%$ for control, blanched, steamed, boiled, and sautéed leaves respectively. Generally, it seemed that heat treatment applied resulted in increased protein content of Moringa leaf powder, except for steaming. This finding was in agreement with study by Kaushik et al. (2010) and Wang et al. (2010) which reported increased in protein after domestic cooking (boiling) in various beans and chickpeas. It was said that the increase in protein was presumably due to the loss of soluble solid during cooking, hence increase the proportion of protein. However, other studies found no significant changes in protein content upon blanching and steaming of Moringa leaves (Titi, Harijono, Estiasih, \& Sriwahyuni, 2013) and upon boiling in lentils (Hefnawy, 2011).

The pepsin digestibility in all treatments were not significantly different $(p>0.05)$. This finding was in agreement with Titi et al. (2013) which reported the same protein digestibility in control, blanched and steamed Moringa leaves with in vitro multienzyme assay.

Table 3. Protein digestibility of Moringa leaf powder and other protein sources

\begin{tabular}{|l|c|c|}
\hline \multicolumn{1}{|c|}{ Commodity } & $\begin{array}{c}\text { Protein Digestibility } \\
(\mathbf{\%})\end{array}$ & References \\
\hline Moringa leaf powder (control) $^{\mathbf{a}}$ & $90.52 \pm 1.58$ & \\
\hline Raw yellow pea flour $^{\mathbf{b}}$ & $83.99 \pm 1.15$ & Ma et al. (2017) \\
\hline Peas (Pisum sativum) $^{\mathbf{b}}$ & $73.5 \pm 1.3$ & Habiba (2002) \\
\hline Soybean (raw) $^{\mathbf{c}}$ & 58 & Gilani et al. (2012) \\
\hline Soybean (boiled) $^{\mathbf{c}}$ & 93 & Gilani et al. (2012) \\
\hline Soybean meal $^{\mathbf{b}}$ & $50-60$ & Bai et al. (2016) \\
\hline
\end{tabular}

abased on in vitro pepsin digestibility

based on in vitro multienzyme digestibility

cbased on true faecal digestibility (in rat)

Table 3 showed the pepsin digestibility of Moringa in comparison to that of other plantbased protein. The limitation in this study was that the protein digestibility was measured only based on protein susceptibility to pepsin with prolonged digestion time. This method is more suitable to assess protein quality for feed. The values of pepsin digestibility in this study $(>84 \%)$ were more than double of that found by Mune Mune et al. (2016), which was 41.11\%. This difference could be due to the difference in cultivar and/or method of analysis since the digestion time with pepsin in this study (16 hours) was considerably longer than in Mune 
Mune's (3 hours). The long duration of enzymatic digestion may increase the measured in vitro protein digestibility (Bai, Qin, Sun, \& Long, 2016).

With the same digestion time, Bai et al. (2016) found that soybean meal only showed 50 - $60 \%$ of protein digestibility with pepsinpancreatin assay. This value was much lower than the pepsin digestibility of raw Moringa leaf powder (control) (90.52\%). Pepsin and pancreatin work complementarily since both enzymes have different specificity. Pepsin preferentially hydrolyzes peptide bond where amino group of aromatic amino acid is located. Pancreatin preferentially hydrolyze peptide bond where carboxylic group of aromatic and basic amino acid are located and the peptide bond where the amino group of aromatic amino acid is located (Mune Mune et al., 2016). It has been demonstrated that further digestion with pancreatin (trypsin, chymotrypsin, chymosin) following that with pepsin increased the protein digestibility (Mune Mune et al., 2016). This information suggested that the use of pepsinpancreatin in combination with long digestion time should have resulted in high protein digestibility. The fact that soybean meal recorded much lower protein digestibility than Moringa with such condition further support
Moringa as alternative protein source to soybean. In addition to that, there is possibility that the multienzyme in vitro protein digestibility of Moringa leaf powder would be even higher than that of soybean meal.

\subsection{Protein digestibility and antinutritional compounds}

A correlation study was carried out between pepsin digestibility with tannins, phytic acid, and saponins using Pearson analysis (Table 4). In this study, pepsin digestibility was almost uncorrelated with tannins ( $\mathrm{r}=0.088)$, which was unexpected because previous studies often demonstrated how tannins adversely affect protein digestibility (Gilani et al., 2005; Gilani, Xiao, \& Cockell, 2012; Ma et al., 2017). Tannin is known as one of major antinutritional compound for protein. Tannins can bind and precipitate proteins including enzymes, reducing the digestibility and amino acid bioavailability or the activity of the enzymes (Liener, 2003). However, in opposite to that, Pushparaj and Urooj (2011) reported positive correlation between protein digestibility and tannins in pearl millet, indicating that other factor might be responsible for the low protein digestibility.

Table 4. Association of pepsin digestibility with tannins, phytic acid, and saponins of Moringa leaf powder

\begin{tabular}{|c|c|c|}
\hline Dependent variable & Independent variables & Correlation coefficient \\
\hline \multirow{3}{*}{ Pepsin digestibility } & Tannins & 0.088 \\
\cline { 2 - 3 } & Phytic acid & 0.135 \\
\cline { 2 - 3 } & Saponins & -0.463 \\
\hline
\end{tabular}

A weak positive correlation was observed between pepsin digesitibility and phytic acid $(\mathrm{r}=0.135)$, but the value was not significant $(\mathrm{p}>0.05)$. Phytic acid or its salt, phytate, is known to chelate cations such as $\mathrm{Ca}, \mathrm{Mg}, \mathrm{Zn}$, and $\mathrm{Fe}$ and interfering with their bioavailability. The antinutritional effect of phytic acid to protein is mainly due to their direct binding to protein (enzyme or substrate) and indirect binding by chelating the mineral cofactors (Gilani et al., 2012). Phytate can form complexes with proteins at both acidic and alkaline $\mathrm{pH}$. Binding of phytic acid and minerals that act as enzyme cofactors will lower the activity of the digestive enzymes, forming insoluble complexes that cannot be absorbed by human intestines (Bessada, Barreira, \& Oliveira, 2019). Meanwhile, formation of protein-phytate complex may alter protein structure that in turn can reduce its enzymatic activity, solubility, and susceptibility to proteolytic enzymes (Konietzny \& Greiner, 2003). Addition of phytase was 
reported to increase the apparent ileal digestibility of nitrogen and amino acids (Gilani et al., 2005).

Among other antinutritional compounds measured, saponin was present at the highest concentration and was the only variable which showed negative correlation with pepsin digestibility $(\mathrm{r}=-0.463)$, although it was not significant $(p>0.05)$. Saponin was better known to interfere with the absorption of dietary lipids, cholesterol, and bile acid (Margier et al., 2018). However, it was also reported that saponins may reduce protein digestibility by forming less digestible saponin-protein complexes. Previous study showed that saponins adversely affect the hydrolysis of soybean protein by chymotrypsin and the digestibility of bovine serum albumin (Francis, Kerem, Makkar, \& Becker, 2002).

The correlation study suggested that saponins was more detrimental to protein digestibility of Moringa leaves than tannins and phytic acid. However, other factor such as dietary fiber and/or molecular structure of the protein may play a role in affecting protein digestibility. Dietary fiber refers to edible fraction of plants that are resistant to digestive enzymes. A reduction in protein digestibility may be due to dietary fiber binding with proteins or acting as physical barrier to proteolytic enzymes (Duodu, Taylor, Belton, \& Hamaker, 2003; Mongeau, Sarwar, Peace, \& Brassard, 1989). Those studies showed that additional and removal of fiber-rich rich components resulted in reduced and improved protein digestibility respectively. Meanwhile, Bai et al. (2016) demonstrated that the percentage of $\beta$-sheet structures of protein was inversely correlated to protein digestibility since $\beta$-sheet structures contained high number of hydrogen bond that may hinder protease activity. However, neither the dietary fiber nor the molecular structure of Moringa protein and their effect to its protein digestibility were not analyzed in this study.

In general, this study suggested Moringa leaves as alternative protein source due to its relatively high protein content and digestibility especially when compared to other plant commodities. Further analysis on protein structure of Moringa leaves, dietary fiber, and their effect on protein digestibility determined with more proper method using Digestible Indispensable Amino Acid Score (DIAAS) are recommended for future studies.

\section{Conclusions}

Moringa oleifera leaves contains high level of protein with considerably high pepsin digestibility. Blanching and boiling increased the protein content but steaming reduced it. The antinutritional compounds reacted differently towards the domestic cooking applied. Steaming and boiling managed to significantly reduce the tannin content. But, phytic acid failed to decrease upon treatments. Instead, blanching and sautéing increased the saponin content. Regardless changes in antinutritional compounds, the domestic cooking applied did not significantly affect the pepsin digestibility. Correlation study showed that among the three antinutritional compounds, it was saponins which adversely affect the pepsin digestibility of Moringa leaf powder. Based on the protein content and pepsin digestibility, this study suggested boiling as the best domestic cooking for Moringa leaves in comparison to blanching, steaming, and sautéing.

\section{References}

Anwar, F., Latif, S., Ashraf, M., \& Gilani, A. H. (2007). Moringa oleifera: a food plant with multiple medicinal uses. Phytotherapy Research, 21, 17-25.

AOAC International, \& Latimer, G. W. (2012). Official methods of analysis of AOAC international (19th ed.). Gaithersburg, Md.: AOAC International.

Azeke, M. A., Egielewa, S. J., Eigbogbo, M. U., \& Ihimire, I. G. (2011). Effect of germination on the phytase activity, phytate and total phosphorus Effect of germination on the phytase activity, phytate and total phosphorus contents of rice (Oryza sativa), maize (Zea mays), millet (Panicum miliaceum), sorghum (Sorghum bicolor) and wheat (Triticum aestivum). Journal of Food Science and Technology, 48(6), 724-729. 
Bai, M., Qin, G., Sun, Z., \& Long, G. (2016). Relationship between molecular structure characteristics of feed proteins and protein in vitro digestibility and solubility. AsianAustralasian Journal of Animal Sciences, 29(8), 1159-1165.

Bessada, S. M. F., Barreira, J. C. M., \& Oliveira, M. B. P. P. (2019). Pulses and food security: Dietary protein, digestibility, bioactive and functional properties. Trends in Food Science and Technology, 93(228), 53-68.

Devisetti, R., Sreerama, Y. N., \& Bhattacharya, S. (2016). Processing effects on bioactive components and functional properties of moringa leaves: development of a snack and quality evaluation. Journal of Food Science and Technology, 53(1), 649-657.

Duhan, A., Khetarpaul, N., \& Bishnoi, S. (2001). Saponin content and trypsin inhibitor activity in processed and cooked pigeon pea cultivars. International Journal of Food Sciences and Nutrition, 52, 53-59.

Duodu, K. G., Taylor, J. R. N., Belton, P. S., \& Hamaker, B. R. (2003). Factors affecting sorghum protein digestibility. Journal of Cereal Science, 38(2), 117-131.

Fabbri, A. D. T., \& Crosby, G. A. (2016). A review of the impact of preparation and cooking on the nutritional quality of vegetables and legumes. International Journal of Gastronomy and Food Science, 3, 2-11.

Francis, G., Kerem, Z., Makkar, H. P. S., \& Becker, K. (2002). The biological action of saponins in animal systems: a review. British Journal of Nutrition, 88, 587-605.

Gilani, G. S., Cockell, K. A., \& Sepher, E. (2005). Effects of Antinutritional Factors on Protein Digestibility and Amino Acid Availability in Foods. Journal of $A O A C$ International, 88(3), 967-987.

Gilani, G. S., Xiao, C. W., \& Cockell, K. A. (2012). Impact of antinutritional factors in food proteins on the digestibility of protein and the bioavailability of amino acids and on protein quality. British Journal of Nutrition, 108, S315-S332.

Habiba, R. . (2002). Changes in anti-nutrients, protein solubility, digestibility, and $\mathrm{HCl}-$ extractability of ash and phosphorus in vegetable peas as affected by cooking methods. Food Chemistry, 77(2), 187-192.

Haug, W., \& Lantzsch, H. (1983). Sensitive method for the rapid determination of phytate in cereals and cereal products. Journal of The Science of Food and Agriculture, 34, 1423-1426. Hefnawy, T. H. (2011). Effect of processing methods on nutritional composition and anti-nutritional factors in lentils (Lens culinaris). Annals of Agricultural Sciences, 56, 57-61.

Hiai, S., Oura, H., \& Nakajima, T. (1976). Color reaction of some sapogenins and saponins with vanillin and sulfuric acid. Planta Medica, 29(2), 116-122.

Johnson, B. (2005). Clinical perspectives on the health effects of Moringa oleifera: a promising adjunct for balanced nutrition and better health. KOS Health Publications.

Kaushik, G., Satya, S., \& Naik, S. N. (2010). Effect of domestic processing techniques on the nutritional quality of the soybean. Mediterranean Journal of Nutrition and Metabolism, 3(1), 39-46.

Konietzny, U., \& Greiner, R. (2003). PHYTIC ACID | Properties and Determination. In Encyclopedia of food sciences and nutrition (pp. 4546-4555).

Liener, I. E. (2003). Plant antinutritional factors/ Detoxification. In B. Caballero, P. Finglas, \& F. Toldra (Eds.), Encyclopedia of food sciences and nutrition (2nd Ed., pp. 45874593).

Ma, Z., Boye, J. I., \& Hu, X. (2017). In vitro digestibility, protein composition and techno-functional properties of Saskatchewan grown yellow field peas (Pisum sativum L.) as affected by processing. Food Research International, 92, 64-78.

Makkar, H. P. S., \& Becker, K. (1996). Nutritional value and antinutritional components of whole and ethanol extracted Moringa oleifera leaves. Animal Feed Science and Technology, 63(1-4), 211-228. Makkar, H. P. S., Blummel, M., Borowy, N. K., 
\& Becker, K. (1993). Gravimetric determination of tannins and their correlations with chemical and protein precipitation methods. Journal of The Science of Food and Agriculture, 61, 161165.

Margier, M., Georgé, S., Hafnaoui, N., Remond, D., Nowicki, M., Du Chaffaut, L., ... Reboul, E. (2018). Nutritional composition and bioactive content of legumes: Characterization of pulses frequently consumed in France and effect of the cooking method. Nutrients, 10(11), 1-12.

Mongeau, R., Sarwar, G., Peace, R. W., \& Brassard, R. (1989). Relationship between dietary fiber levels and protein digestibility in selected foods as determined in rats. Plant Foods for Human Nutrition, 39(1), 45-51.

Moyo, B., \& Masika, P. (2011). Nutritional characterization of Moringa (Moringa oleifera Lam.) leaves. African Journal of Biotechnology, 10(60), 12925-12933.

Mune Mune, M. A., Nyobe, E. C., Bassogog, C. B., \& Minka, S. R. (2016). A comparison on the nutritional quality of proteins from Moringa oleifera leaves and seeds. Cogent Food \& Agriculture, 2(2), 1-8.

Olabode, Z., Akanbi, C., Olunlade, B., \& Adeola, A. (2015). Effects of drying temperature on the nutrients of Moringa (Moringa oleifera) leaves and sensory attributes of dried leaves infusion. Direct Research Journal of Agriculture and Food Science, 3(5), 117-122.

Pushparaj, F. S., \& Urooj, A. (2011). Influence of Processing on Dietary Fiber, Tannin and in Vitro Protein Digestibility of Pearl Millet. Food and Nutrition Sciences, 2, 895-900.

Sallau, A. B., Mada, S. B., Ibrahim, S., \& Ibrahim, U. (2012). Effect of boiling, simmering and blanching on the antinutritional content of Moringa oleifera leaves. International Journal of Food Nutrition and Safety, 2(1), 1-6.

Savage, G. P. (2003). Saponins. In Encyclopedia of Food Sciences and Nutrition (pp. 50955098).
Sreerama, Y. N., Sashikala, V. B., Pratape, V. M., \& Singh, V. (2012). Nutrients and antinutrients in cowpea and horse gram flours in comparison to chickpea flour: Evaluation of their flour functionality. Food Chemistry, 131(2), 462-468.

Teixeira, E. M. B., Carvalho, M. R. B., Neves, V. A., Silva, M. A., \& Arantres-Pereira, L. (2014). Chemical characteristics and fractionation of proteins from Moringa oleifera Lam . leaves. Food Chemistry, 147, 51-54.

Titi, M., Harijono, Estiasih, T., \& Endang, S. (2013). Effect lactagogue moringa leaves (Moringa oleifera Lam) powder in rats white female wistar. Journal of Basic and Applied Sceintific Research, 3(4), 430-434.

Titi, M., Harijono, Estiasih, T., \& Sriwahyuni, E. (2013). Effect of blanching treatments against protein content and amino acid drumstick leaves (Moringa oleifera). Journal of Food Research, 2(1), 101-108.

United States Department of Agriculture (USDA). (2019). FoodData Central. Retrieved from https://fdc.nal.usda.gov/fdcapp.html\#/food-details/174273/nutrients

Wang, N., Hatcher, D. W., Tyler, R. T., Toews, R., \& Gawalko, E. J. (2010). Effect of cooking on the composition of beans (Phaseolus vulgaris L.) and chickpeas (Cicer arietinum L.). Food Research International, 43(2), 589-594.

Yang, R.-Y., Tsou, S. T. S., \& Lee, T.-C. (2002). Effect of cooking on in vitro iron bioavailability of various vegetables. In T. C. Lee \& C. T. Ho (Eds.), Bioactive compounds in foods. Effects of processing and storage (pp. 130-142).

\section{Acknowledgement}

The authors thank Directorate General of Higher Education, Indonesia for the financial support through National Competitive Grant PDP Scheme and to Research Office of Universitas Prasetiya Mulya for the support on this project. 